\title{
Recommendations of Strategies for Significant Learning in U-Learning Environments
}

\author{
Josilene Almeida Brito \\ Federal Institute of Sertão \\ Pernambucano (IF-Sertão) - \\ Brazil \\ Rosangela Maria de Melo \\ Federal Institute of Pernambuco - \\ (IFPE) - Brazil
}

\author{
Ivanildo José de Melo Filho \\ Federal Institute of Pernambuco - \\ (IFPE) - Brazil
}

\author{
Bruno de Sousa Monteiro \\ Federal University of Semi-Arido \\ - (UFERSA) - Brazil
}

\author{
Luma da Rocha Seixas \\ Federal University of \\ Pernambuco - (UFPE) - Brazil
Alex Sandro Gomes
Federal University of \\ Pernambuco-(UFPE) - Brazil
}

\section{Abstract}

The resources of mobile and ubiquitous technologies allow learners a new possibility of learning in specific contexts, contextualized and extendable to the real environment. While performing the activities in the field, one perceives differences of behaviors and of knowledge among the apprentices. At this point, ubiquitous computing tools can extend the benefits to learning by considering the context in which the learner is. However, the design of Ubiquitous Learning Environments (U-Learning), which meets all these innovative features of continuous mobility, is not a simple task due to the peculiar characteristics of the supporting devices: heterogeneity, limited battery, scarce computational resources, among others. This work presents a set of recommendations for strategies for meaningful learning in a U-learning environment, arising from needs identified through a ubiquitous learning platform, through an experiment carried out at a Federal Institution in the Northeast of Brazil culminating in the proposal of recommendations of improvements in learning activities that allow greater assistance to the learner through the environment and to the teacher, favoring the characteristics for meaningful ubiquitous learning.

\section{Introduction}

The resources of mobile and ubiquitous technologies allow learners a new possibility of learning in specific contexts, contextualized and extendable to the real environment. While performing the activities in the field, one perceives differences of behaviors and of knowledge among the apprentices. At this point, ubiquitous computing tools can extend the benefits to learning by considering the context in which the learner is. [1];[2].

However, the design of ubiquitous learning environments, which meets all these innovative characteristics of continuous mobility, is not a simple task due to the peculiar characteristics of the supporting devices: heterogeneity, limited battery, scarce computational resources, among others [3]. In this context, the authors, the authors [4] corroborate, stating that whenever possible, functionalities should be developed that promote the interactivity between learner, environment and teacher.
The literature presents investigations that discuss the significant learning in the ubiquitous modality, as guiding elements for the evaluation of the ubiquitous learning in environments of learning based in the context. The authors [5] developed a ubiquitous learning module based on the Moodle platform, with the purpose of promoting better results in the effective learning of learners in the environment. The great differential of the proposed learning system uses the dimension of personalized learning through the provision of learning material in the open air, aiming to increase its capacity and interest in learning.

The study of [6] aimed to investigate how ubiquitous games influence the teaching of the English language, evaluating the dimensions of satisfaction in learning and motivation through a ubiquitous learning based on context. To evaluate motivation and satisfaction with use, educational strategies were included, including ubiquitous gamebased learning, collaborative learning and augmented reality capabilities to enable learners to experience real-world emotions and feelings in a virtual environment with the aim of involving learners in learning activities based on motivation theory.

In this context, we also highlight the study by [7];[8];[9] which describes the ubiquitous learning environment called Youubi, open source, compatible with Android application for mobile smartphones. The proposed model incorporates learning challenges in the form of activities, using geolocation resources between teachers and apprentices, proposing an evaluation of the acceptance of the environment, in order to determine if there was acceptance, motivation and engagement between teachers and learner. As a result, those involved have identified the Youubi ulearning environment as an important ally for their practices.

\section{Meaningful Learning}

According to [10], meaningful learning occurs when the individual can establish coherent relationships between what he already knows and the new knowledge that is being presented. Significant learning is based on the assimilation theory of [11]. It uses the term "significant" to identify the process of interaction between the new information acquired by the individual and the relevant knowledge that he or she already possesses [12];[13]. 
In these terms, in order to learn meaningfully, people must take responsibility for their own learning, and the material available for learning must have a logical meaning (depending on the material) and a psychological meaning (depending on the level of experience every apprentice has). Thus, the apprentices themselves involved in the process will filter the materials that have meaning or not.

On the other hand, learners must be intentionally engaged in combining prior knowledge with new knowledge, applying theoretical ideas, organizing and structuring content in a coherent way [12].

It should be emphasized that this engagement will be due to the level of motivation of learners to learn. According to what [14] propose, "behaviors motivated intrinsically are based on people's needs to feel competence and self-determination." The authors postulate that people become interested in activities as they feel fulfilled their needs for autonomy and competence. The authors believe that the satisfaction of this need is essential for maintaining intrinsic motivation.

Following this line of reasoning, meaningful learning is considered an active process, resulting from the interaction between previous and new knowledge, favoring a deeper and deeper understanding of the concepts. Such interaction is due to changes in knowledge acquired in the skills acquired over time.

\section{Youubi Plataform}

According to [7];[8];[9], the Youubi environment is composed of a client-server architecture. The
Youubi API, provides 63 methods for implementing web services. These services enable developers to build client applications with requirements for: social networking, content creation, gamification, and recommendations based on user context.

The Youubi environment considers the following variables as context: static profile information (name, age, course, profession and gender), privacy preferences, user geographical coordinates, user movement speed, device status (battery, screen, connection and operating system), list of friends, list of interacted contents, list of tags and subjects of interest.

To better understand future scenarios with Youubi, it is important to understand their elemental entities. They refer to data model entities that represent users (Person) and other objects (Post, Events, Question in Quiz, Place, Group, and Mission) that can be created and manipulated by users.

All these entities are geolocalized into attributes and can be represented by a QR code. This association allows them to point to real places. In addition to these attributes, there are other more common ones such as title, description, URL and image.

\section{Methodological Design}

The methodological design consisted in the realization of an experiment during 5 weeks in an intercalated way using teaching activity in traditional classroom and the urban space in the municipality of Petrolina - Pernambuco -- Brazil. The ubiquitous environment used was the Youubi as described in the previous section.

\section{\begin{tabular}{l|l|l|l|l} 
WEEK 1 & WEEK 2 & WEEK 3 & WEEK 4 & WEEK 5
\end{tabular}}

(1)

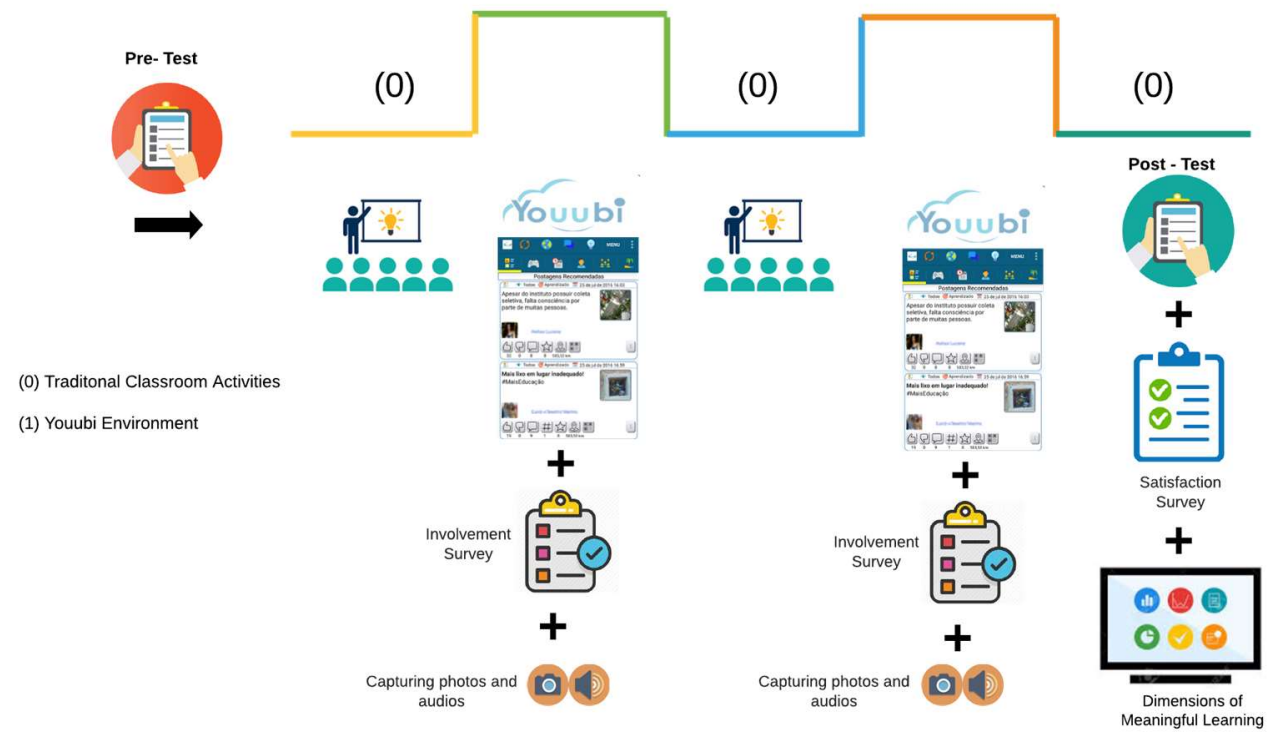

Figure 1. Summary of the flow of the methodological design applied in all phases for the collection of the data each week with their respective collection instruments. [1];[2]. 
The participants are were students of of Technical courses in Computer Science and Chemistry and the content addressed in the experiment was related to the teaching of Geography. Considering the space limit established by LICEJ, the details regarding this stage can be consulted in [1]; [2].

The Figure 1 summarizes the flow used in all phases to collect data each week with their respective collection instruments. It should also be noted that these instruments are detailed in [1];[2]. The Figure 1 shows each instrument used in the data collection with the execution of the learning activities by the learners.

\section{Elicitation of Requirements for Ubiquitous Meaningful Learning}

Based on the needs identified during the experiment described in Figure 1 and detailed in [1];[2], aiming for greater interactivity between apprentices, teachers and the learning environment, the need arose to propose recommendations that favor ubiquitous meaningful learning strategies for the teacher and for the learner, enriched by information (perception) of the user's state, the state of the physical environment and the history of user interactions to ensure the necessary mobility.

TABLE 1. CHARACTERISTICS OF A UBIQUITOUS LEARNING ENVIRONMENT IDENTIFIED IN THE THEORY WITH THE CHARACTERISTICS PRESENT

\begin{tabular}{|c|c|c|c|}
\hline $\begin{array}{c}\text { Ubiquitous } \\
\text { Learning Strategy }\end{array}$ & Description & $\begin{array}{c}\text { Current Features on } \\
\text { Youubi }\end{array}$ & Recommendations \\
\hline $\begin{array}{l}\text { Learning in the real } \\
\text { world with online } \\
\text { guidance }\end{array}$ & $\begin{array}{l}\text { Apprentices learn in the real } \\
\text { world and are guided by the } \\
\text { system, based on the personal } \\
\text { profile, portfolio and real-world } \\
\text { data collected by the sensors. }\end{array}$ & $\begin{array}{l}\text { Apprentice creates post } \\
\text { where it is. }\end{array}$ & $\begin{array}{l}\text { The environment should propose } \\
\text { content according to the profile of } \\
\text { the learner and the group of which he } \\
\text { is a part (content previously } \\
\text { registered by the teacher), as well as } \\
\text { automatically provides suggestions } \\
\text { to the learner. }\end{array}$ \\
\hline $\begin{array}{l}\text { Real-world learning } \\
\text { with online support }\end{array}$ & $\begin{array}{l}\text { Apprentices learn in the real } \\
\text { world, and support is provided } \\
\text { by the system automatically, } \\
\text { based on the personal profile and } \\
\text { actual portfolio. }\end{array}$ & $\begin{array}{l}\text { Present resource to } \\
\text { support online. }\end{array}$ & $\begin{array}{l}\text { Allow the learner to consult online } \\
\text { relevant information (eg. features) } \\
\text { geolocalized for the proposed } \\
\text { content. }\end{array}$ \\
\hline Test online & $\begin{array}{l}\text { The learner is asked to answer } \\
\text { questions presented through the } \\
\text { mobile device. }\end{array}$ & $\begin{array}{l}\text { Creating postings and } \\
\text { quiz challenges. }\end{array}$ & $\begin{array}{l}\text { Provide quiz in the form of } \\
\text { challenges in a certain location } \\
\text { (geolocalized) referring to the } \\
\text { subject previously defined. }\end{array}$ \\
\hline $\begin{array}{l}\text { Suggest activities } \\
\text { by location }\end{array}$ & $\begin{array}{l}\text { The apprentice is notified when } \\
\text { he is in a certain place and this is } \\
\text { related to some activity. }\end{array}$ & $\begin{array}{l}\text { Youubi only } \\
\text { geolocalizes the created } \\
\text { activities. }\end{array}$ & $\begin{array}{l}\text { Notify the learner in accordance } \\
\text { with their geolocation and ongoing } \\
\text { activities. }\end{array}$ \\
\hline $\begin{array}{l}\text { Perform real-world } \\
\text { observations and } \\
\text { collect data }\end{array}$ & $\begin{array}{l}\text { Apprentices are invited to } \\
\text { observe real world data and } \\
\text { collect them through mobile } \\
\text { devices. }\end{array}$ & $\begin{array}{l}\text { You create posts and } \\
\text { challenges, using } \\
\text { images collected in the } \\
\text { real world and made } \\
\text { available in the Youubi } \\
\text { environment. }\end{array}$ & $\begin{array}{l}\text { Collect data through audios and } \\
\text { videos. }\end{array}$ \\
\hline
\end{tabular}

Taking into consideration also the architecture of the ubiquitous learning environment Youubi, we used the evaluative parameters, defined by [15], in which the importance of evaluating the detection resources to carry out learning activity in the real world, which were referenced to the system (detecting the learner's personal situation and the situation of the environment) and extracting personal data from the database (including the learner's profile, his choices during the learning process, the timeline learning activities, on-site learning activities, on-site equipment and people in use in the environment).

Based on the parameters derived from the researched theory of learning strategies listed by [16], we took as a guiding element in the analysis, the ULearning models, highlighted in Table 1, which were used to evaluate and propose recommendations of functionalities that contemplate a better perception about apprentices' learning by analyzing their behavior in real time.

The Table 1 compares the characteristics of a ubiquitous learning environment identified in the theory with the characteristics present in the Youubi environment and possible recommendations. environment. 


\section{Pedagogical Pedagogical Requirements for Ubiquitous Learning Strategies}

In addition to the characteristics described in Table 1 , specific to a ubiquitous learning environment, it should also incorporate pedagogical requirements in order to facilitate and support learning activities. These requirements are directly related to the interactivity, motivation and adaptation to the context of the learners, promoting an appropriate environment to the educational practices that favor a greater assistance to the apprentice and also to the teacher accompaniment.

It should be emphasized that the possibilities indicated were derived from the investigation of related works, difficulties identified and converted into the needs pointed out by the apprentices, by the professor of geography and by the researcher during the experiment, described in Table 2.

TABLE 2. PEDAgogicAl ReQUiREMENTS FOR UbiQuitous LEARNING STRATEGIES.

\begin{tabular}{|c|c|c|}
\hline Difficulties & Possibilities & Requirements \\
\hline $\begin{array}{l}\text { Using the post via text, in the real context, } \\
\text { does not enhance the learner's total } \\
\text { perception of the context. }\end{array}$ & Allow audio discussion. & Reply to posts using audio. \\
\hline $\begin{array}{l}\text { The system counts all comments that the } \\
\text { learner makes. This causes a user to make } \\
\text { a lot of comments; however, these may not } \\
\text { be directly related to the purpose of the } \\
\text { activity. }\end{array}$ & $\begin{array}{l}\text { Post only comments that are } \\
\text { relevant. }\end{array}$ & $\begin{array}{l}\text { Notify teacher about the comment or } \\
\text { posting, made by the apprentices, so that } \\
\text { he can evaluate it according to the } \\
\text { categories defined in Table } 1 \text {. }\end{array}$ \\
\hline $\begin{array}{l}\text { Apprentices and teacher do not have real- } \\
\text { time insight into the interactions in the } \\
\text { activities created by them. }\end{array}$ & $\begin{array}{l}\text { Increase the perception about } \\
\text { interactions in learning activities } \\
\text { (comment and response) in real } \\
\text { time. }\end{array}$ & $\begin{array}{l}\text { Notify the author of each interaction } \\
\text { received. Example: Notify each comment } \\
\text { and challenge answered. }\end{array}$ \\
\hline Absence of a QR Code and Tag reader. & Read QR code and Tag. & Insert a QR Code Tag Reader \\
\hline $\begin{array}{l}\text { Absence of material to support the } \\
\text { apprentice during successive incorrect } \\
\text { attempts at realizing the challenges in the } \\
\text { form of Quiz. }\end{array}$ & $\begin{array}{l}\text { Suggest support material when } \\
\text { the learner performs activity } \\
\text { incorrectly more than once. }\end{array}$ & $\begin{array}{l}\text { Suggest content (links or texts) to assist } \\
\text { the learner in carrying out the activity. }\end{array}$ \\
\hline
\end{tabular}

Aiming for an improvement in associating relevant contextual information to explore learner profile characteristics that assist in a personalization of service recommendations, Table 3 presents recommendations for the learner profile.

TABLE 3. ReCOMmendations FOR THE LEARNER PROFILE.

\begin{tabular}{|l|l|l|}
\hline \multicolumn{1}{|c|}{ Difficulties } & \multicolumn{1}{|c|}{ Possibilities } & \multicolumn{1}{c|}{ Requirements } \\
\hline $\begin{array}{l}\text { The learners does not have a perception } \\
\text { about his or her history of accomplishment } \\
\text { of the activities. }\end{array}$ & $\begin{array}{l}\text { Expand the perception of the } \\
\text { apprentice informing the status } \\
\text { of their activities (carried out, in } \\
\text { progress and to be carried out). }\end{array}$ & $\begin{array}{l}\text { Create a learner's history with activities } \\
\text { status (performed, in progress, and to be } \\
\text { performed). }\end{array}$ \\
\hline $\begin{array}{l}\text { The learner does not meet individual } \\
\text { learning needs. }\end{array}$ & $\begin{array}{l}\text { Recommend activities } \\
\text { according to the profile of the } \\
\text { learner. }\end{array}$ & $\begin{array}{l}\text { Use other learner profile information (a } \\
\text { content, people close, activity discussed) } \\
\text { to recommend activities that are } \\
\text { appropriate to the needs of each learner. }\end{array}$ \\
\hline $\begin{array}{l}\text { The environment offers few opportunities } \\
\text { for learners to inform their interests. }\end{array}$ & $\begin{array}{l}\text { Apprentice configures or selects } \\
\text { content of interest to enrich your } \\
\text { profile. }\end{array}$ & $\begin{array}{l}\text { Allow the trainee to customize his } \\
\text { profile according to his interests. }\end{array}$ \\
\hline $\begin{array}{l}\text { The environment does not notify about } \\
\text { unrealized activities. }\end{array}$ & $\begin{array}{l}\text { Recommends an unrealized } \\
\text { activity. }\end{array}$ & $\begin{array}{l}\text { Notify the learners of unrealized } \\
\text { activities in the environment. }\end{array}$ \\
\hline
\end{tabular}

Once the identified contextual needs have been presented to explore learner profile characteristics that aid in personalization for service recommendations. The following section details recommendations for teacher support in trainee monitoring in the ULearning environment. 


\section{Recommendations to the Teacher to Accompany the Learners in the Youubi Environment.}

It is difficult for most teachers to plan and develop learning strategies in U-Learning environments that contemplate specific activities in the real world. In this context, [17], corroborates that: "It is necessary to help the teacher to develop new educational practices, not focused on technology, but in the process of student learning using technology".

Thus, it is necessary for the environment to make recommendations that assist the trainees in the environment, taking into account the actions taken by the learners (Table 4)

TABLE 4. RECOMMENDATIONS TO THE TEACHER TO ACCOMPANY THE LEARNERS IN U-LEARNING ENVIRONMENT.

\begin{tabular}{|l|l|l|}
\hline \multicolumn{1}{|c|}{ Difficulties } & \multicolumn{1}{|c|}{ Possibilities } & \multicolumn{1}{c|}{ Requirements } \\
\hline $\begin{array}{l}\text { The system does not classify the } \\
\text { comments made by the apprentices in the } \\
\text { environment, making it difficult to } \\
\text { visualize learner performance. }\end{array}$ & $\begin{array}{l}\text { Evaluate learners' comments } \\
\text { on the environment. }\end{array}$ & $\begin{array}{l}\text { View learner comment notifications and } \\
\text { validate comment type. }\end{array}$ \\
\hline $\begin{array}{l}\text { The teacher has difficulty accessing the } \\
\text { interactions in comments and responses of } \\
\text { learners in the environment. }\end{array}$ & $\begin{array}{l}\text { Allow to organize textual } \\
\text { information - content } \\
\text { produced in activities more } \\
\text { clearly prosent reports of learner performance } \\
\text { according to the interactions shown (student } \\
\text { where he is, content he produced } \\
\text { with his performance, in report form) }\end{array}$ \\
\hline $\begin{array}{l}\text { The teacher does not have the perception } \\
\text { of the learners who are not participating in } \\
\text { the activities }\end{array}$ & $\begin{array}{l}\text { Permit to identify which } \\
\text { learner was } \\
\text { participating, to be able to } \\
\text { intervene and help and } \\
\text { stimulate their participation } \\
\text { in the environment. }\end{array}$ & $\begin{array}{l}\text { Provide mechanisms of social perception } \\
\text { and interaction that enable interactions in the } \\
\text { environment so that teachers interact } \\
\text { efficiently in the process. }\end{array}$ \\
\hline
\end{tabular}

\section{Final Considerations}

The main motivation for proposing recommendations for ubiquitous meaningful learning strategies in U-Learning environments was the lack of standards in relation to specific characteristics and requirements that contemplate the context of learning from real-world observations.

The proposed recommendations were defined and detailed through the investigation of related works, of needs pointed out by the apprentices, professor of the discipline and professor researcher. Difficulties, characteristic needs of identified requirements, as well as help in the design and development of new ubiquitous meaningful learning strategies, make it easier for recommendations to assist the apprentices in the environment, taking into account actions taken anywhere, anytime.

Therefore, it is important to define these recommendations in order to understand and understand the context of ubiquitous learning, especially in relation to its construction and use in the experiment, involving the teacher and apprentices, in the real situation of ubiquitous learning. One of the main objectives of the proposed recommendations, along with the characteristics of requirements, had as motivating element, to help in the proposal of recommendations, that help the follow-up of the apprentices in the environment by the teacher, taking into account the actions taken by the apprentices.

\section{References}

[1] BRITO, J. A. ; SEIXAS, L. R.; MELO FILHO, I. J. ; GOMES, A. S. ; MONTEIRO, B S. . Meaningful Learning in ULearning Environments: An Experience in Vocational Education. In: Óscar Mealha; Monica Divitini;Matthias Rehm. (Org.). Smart Innovation, Systems and Technologies. Ied.Aveiro/Portugal: Springer International Publishing, 2018, v. I, p. 31-38.

[2] BRITO, J. A. ; MONTEIRO, B. S. ; GOMES, A. S. ; AMORIM, R. ; SEIXAS, L. R. ; MELO FILHO, I. J. . ULearning: A Collaborative Experience in the Urban Context. LECTURE NOTES IN COMPUTER SCIENCE (INTERNET), v. 10391, p. 40-48, 2017.

[3] MARINHO, F. G.; MAIA, M. E. F. ; DANTAS, V. L. L. ; ROCHA, L. S. ; VIANA, W. ; ANDRADE, R. M. C. ; TEIXEIRA, E. ; WERNER C.A Software Product Line for the Mobile and Context-Aware Applications Domain. In: 14th Software Product Line Conference, 2010, Jeju Island. 14th Software Product Line Conference, 2010.

[4] YEN JC, LEE CY. Exploring problem solving patterns and their impact on learning achievement in a blended learning environment. Computers \& Education. 2011 Jan 1;56(1):13845.

[5] CHANG Wan-Jen; Z.M. Yeh. A. Case Study of Service Learning Effectiveness based on Ubiquitous learning system for College Students. Procedia - Social and Behavioral Sciences 136 ( 2014 ) $554-558$

[6] LIU, LIU TY, CHU YL. Using ubiquitous games in an English listening and speaking course: Impact on learning outcomes and motivation. Computers \& Education. 2010 Sep $1 ; 55(2): 630-43$.

[7] MONTEIRO, B., de S. Ambiente de aprendizado ubíquo youubi: design e avaliação. Tese de doutorado em Ciencia da Computação. UFPE, Recife, 2015.

[8] MONTEIRO, B. S.; GOMES, A. S. Ubiquitous Technologies and the Emergence of New Learning Experiences. Technology Platform Innovations and Forthcoming Trends in Ubiquitous Learning. 1ed.: IGI Global, 2014, v. , p. 142-159. 
[9] MONTEIRO, B. S.; OLIVEIRA, EVERTON JALES DE ; Gomes, Alex Sandro ; NETO, FRANCISCO MENDES . Youubi: Ambiente de Aprendizagem Ubíqua. In: XXVI Simpósio Brasileiro de Informática na Educação, 2015, Maceió, 2015. p. 111.

[10] MOREIRA M. A. APRENDIZAGEM SIGNIFICATIVA: da visão clássica à visão crítica (Meaningful learning: from the classical to the critical view). In: Conferência de encerramento do $\mathrm{V}$ Encontro Internacional sobre Aprendizagem Significativa, Madrid, Espanha, setembro de 2006.

[11] AUSUBEL, David P. "The psychology of meaningful verbal learning." (1963).

[12] CADORIN, L. Meaningful Learning in Healthcare Professionals: Integrative Review and Concept Analysis. The European Conference on Education 2013.iafor The International Academic Forum www.iafor.org.

[13] BAGNASCO, A. et al. 2015.Instruments measuring meaningful learning in undergraduate healthcare students: a systematic review protocol.

[14] RYAN RM, DECI EL. Intrinsic and extrinsic motivations: Classic definitions and new directions. Contemporary educational psychology. 2000 Jan 1;25(1):54-67.

[15] HWANG GJ, TSAI CC, YANG SJ. Criteria, strategies and research issues of context-aware ubiquitous learning. Journal of Educational Technology \& Society. 2008 Apr 1;11(2):8191.

[16] SACCOL, A. M-learning e u-learning: novas perspectivas das aprendizagens móvel e ubíqua / Amaralina Saccol, Eliane Schlemmer, Jorge Barbosa. São Paulo: Pearson Prentice Hall, 2011. ISBN 978-85-7605-377-4.

[17] SEVERIN, E. Entrevista: "Tecnologia é só parte da solução". Instituto Inspirare, 2012. Disponível em: $<$ http://porvir.org/porpessoas/tecnologia-e-so-parte-dasolucao-diz-eugenio-severin/>. Acesso: 28 out. 2018. 